\title{
Does Revitalizing the Center of Mid-Sized French Cities Reduce GHG Emissions from Commuting?
}

\author{
Alexis Poulhès ${ }^{1,2, *}$ and Angèle Brachet ${ }^{2}$ \\ 1 LVMT, Ecole des Ponts, Université Paris Est, 6-8 avenue Blaise Pascal, 77420 Champs-sur-Marne, France \\ 2 Efficacity, 14-20 Boulevard Newton, 77447 Marne-la-Vallée, France; a.brachet@efficacity.com \\ * Correspondence: alexis.poulhes@enpc.fr
}

check for

updates

Citation: Poulhès, A.; Brachet, A

Does Revitalizing the Center of

Mid-Sized French Cities Reduce GHG

Emissions from Commuting?.

Sustainability 2021, 13, 1851.

https://doi.org/10.3390/su13041851

Received: 16 October 2020

Accepted: 26 January 2021

Published: 8 February 2021

Publisher's Note: MDPI stays neutral with regard to jurisdictional claims in published maps and institutional affiliations.

Copyright: (c) 2021 by the authors. Licensee MDPI, Basel, Switzerland. This article is an open access article distributed under the terms and conditions of the Creative Commons Attribution (CC BY) license (https:// creativecommons.org/licenses/by/ $4.0 /)$.

\begin{abstract}
Mid-sized cities are usually considered in the literature to be shrinking cities. Some policies promote right-sizing and others promote revitalization. The relationship between land-use planning and mobility having been established, the present research issue is focused on whether a policy of revitalizing the centers of mid-sized cities is favorable to low-carbon mobility. Our study investigates commuting trips through two indicators: commuting trip distance and car modal share. The increase in total population, the increase in the number of jobs per resident, the decrease in the unemployment rate, the increase in the rate of executives, the increase in the rate of working people in the population and the decrease in the residential vacancy rate all come from the censuses of 2006 and 2016. Statistical models based on individuals in 113 mid-sized cities, in which sociodemographic variables are introduced, show that at the level of agglomerations, no indicator has a simultaneously positive effect in the center and in the urban periphery. No indicator is entirely positive or negative on GHG emissions from commuting trips. While the increase in GHG emissions from commuting trips between 2006 and 2016 is significant in mid-sized cities (18\%), a shift toward shrinking city centers is insufficient to change this trajectory.
\end{abstract}

Keywords: mid-sized cities; commuting; revitalization

\section{Introduction}

The dependency of residents not living in major cities on their private cars is a social and environmental issue that is increasingly central in urban policies [1]. Mobility is becoming a central public policy issue in mid-sized cities, since the near-exclusive use of private cars in such cities is not compatible with reducing greenhouse gas emissions. However, the difficulty of providing alternative modes and the resulting car dependency limit the scope of action for urban policies. Moreover, mid-sized cities in developed countries are often challenged by social and economic issues [2] as well as significant devitalization. Their economic attractiveness is limited compared to the major cities offering the largest number and variety of jobs [3]. Policies to encourage "right-sizing" shrinkage are being studied, mainly in the United States [4], where land use is changing more quickly than in Europe. Béal et al. [4] studied two French cities in economic difficulty where this policy was implemented, though without being named as such. Conversely, other types of actions aim to reverse these shrinkage trajectories. Such is the case of the French government, which decided in 2018 to help 222 cities to revitalize their centers through the "Action Coeur de ville" program [5], under which they receive sizable financial and legal support to refurbish residential and retail areas.

Urban policies lead in the more or less long term to significant changes in urban forms. Numerous studies show that the denser a city is or the stronger its functional mix, the lower the GHGs from residents' mobility [6-9]. As the link between urban forms of cities and GHG emissions from residents' trips is no longer established, it is questionable whether the revitalization of city centers can reduce car use. Could a policy of revitalizing central towns reduce the distance traveled by car and, therefore, the environmental impact of mobility? 
The literature on urban dynamics, such as "shrinking cities" or "urban renewal", is quite rich. Similarly, the link between urban forms and GHGs from daily mobility is the subject of many studies. However, the impact of urban dynamics on mobility behavior is much less studied, especially in mid-sized cities, which remain relatively unstudied. The dynamics of mid-sized cities are often observed through the prism of shrinking cities. The classical definition of shrinking cities is that the population of these cities is decreasing [10]. In the French case, even if the population of the city or urban area does not shrink, the transfer of the population from the center to the surrounding areas represents a different form of shrinkage [11]. In analyzing the phenomenon of shrinkage in several developed countries, Martinez-Fernandez et al. recommend focusing on the social aspect: diversifying economic activities for more resilience and attracting people by being flexible and creative [2]. Over the last 30 years, American cities have experienced a continuity of growth or decline trajectories, with no surprises along the way [12]. On the other hand, economically, cities can have trajectories that are totally unrelated to population variations. In Europe, this relationship seems clearer. Cities that continually lost their population between 1990 and 2010 are mainly Eastern European cities in economic difficulty [13]. In France, at the urban area level, there are few shrinking cities [14]. The authors highlight five city profiles; except for cities with a very high unemployment rate, the other profiles remain socially or economically attractive.

The study of the opposite type of policy-induced dynamics is widely documented using different terms in the literature. Some speak of regeneration or renewal with, for example, the following definition: "aims at improving the physical, socioeconomic and ecological aspects of urban areas through various actions" [15]. Others use the same definition to speak of revitalization $[16,17]$ whose objective is to reverse a shrinkage dynamic [18]. We focus on some of the much less numerous studies that explore the connections between this dynamic and mobility. The first study calculates the probabilities of modal shift and decreasing commuting distance according to the jobs/household ratio and to density, but only at the scale of the urban renewal district [19]. The second study analyzes the effect of gentrification on commuting behaviors in the urban centers of large American cities [17]. Bereitschaft [17] shows the link between gentrification and the increase in active modes and public transport. According to Florida [20], gentrification is at the foundation of the usual process of wealth creation in a shrinking territory and is, therefore, a frequent step in the revitalization process, whether this process is planned or not. Criticisms of this gentrification are numerous, especially regarding the expulsion of poorer populations, who are thus evicted to less central areas. These poor people who move to less densely populated areas are thus the populations that increase their distance from the center the most [21]. These studies [17,19] have limited themselves to assessing changes in behavior only within the perimeters of changes in population. However, the interactions between the districts of a city are such that from an environmental point of view, urban evolution can only be evaluated at the scale of the whole urban area. On the link between residential vacancy and mobility, research has highlighted that in England, the regulation of residential vacancy has had the effect of increasing commuting distances [22]. Other studies have focused more specifically on the $\mathrm{CO}_{2}$ emissions of shrinking cities. In China, it has been found that shrinking cities have difficulty reducing their $\mathrm{CO}_{2}$ emissions compared to cities that continue to grow, largely due to the fact that the remaining industries are the most polluting [23]. Focusing on carbon emissions from residences and travel, a study shows that Chinese shrinking cities tend to reduce their efficiency compared to other cities [24]. Interaction effects highlight the complexity of the relationship between the economy, carbon emissions and shrinkage. These studies focus on discussions about industry, the main Chinese issue in terms of GHG emissions, rather than on mobility.

Revitalization actions can be evaluated based on indicators of urban dynamics. How does the recent evolution of these indicators for 113 cities influence commuting? This question leads to an overview of the impact of future revitalization. We then focus on the recent evolution of city center vitality. Vitality is complex to evaluate. This study 
uses several indicators to define the activity of residents, such as the unemployment rate or the ratio of jobs in the working population. It draws on data on 113 mid-sized cities from the 2006 and 2016 French national censuses to compare the changes in their vitality. Commuting, which is well documented and directly affected by revitalization, and changes in urban forms [15] are studied through modal shift and distance to the workplace. An initial analysis looks at modal choice and distance between home and workplace in relation to the urban context and the evolution of vitality. Next, $\mathrm{CO}_{2}$ emissions from commuting trips are assessed with distances traveled in different modes. A multivariate analysis isolates the impact of the vitality of central towns and its evolution over 10 years from the socio-demographic characteristics of households in each city.

\section{Data and Method}

\subsection{Study Area}

This research focuses on the territories of French mid-sized cities. There is obviously no precise definitional boundary separating mid-sized cities, larger conurbations with a more regional influence and what we call small towns that are more dependent on mid-sized cities. That is why there are numerous coexisting definitions for the mid-sized city $[25,26]$. The one most commonly used by geographers who study the links between home and work considers a population segment around the urban area [3,27]. However, this is not the definition used by the authorities responsible for setting subsidies and taxes. In particular, the rates of business contributions increase when the size of the urban population exceeds 100,000 (Article L. 2333-65 of the French "Code des colletivités territoriales"). Indeed, it is noticeable that cities which do not receive the transport subsidy have not developed tram systems (with the exception of Aubagne with a $2.5 \mathrm{~km}$ network, and Avignon which is in the process of building one). In France, bus networks do not play a structuring role, and the modal share of public transport in conurbations does not exceed $6 \%$ for commuter journeys. Therefore, it seems consistent with mobility practices to apply a more political definition. For this reason, we choose to identify a mid-sized city by means of population size. We use the definition employed by the Fédération Villes de France, which encompasses all towns in the center of an urban area with a population of between 20,000 and 100,000: it excludes towns that fall within this population bracket but are located within the urban area of a larger conurbation. This categorization is also used by the government to define the cities which are eligible for the "Action Coeur de Ville" revitalization plan.

In order to assess mid-sized cities and their evolution since 2006, the whole urban area of a city has to be considered. According to the National Institute of Statistics and Economic Studies (INSEE) definitions, an urban area is a continuous group of municipalities within which $40 \%$ of the resident working population is employed in an urban ring. This urban ring is a group of municipalities, each having more than 2000 inhabitants and 1500 jobs, in which the largest locality is the central town. In the rest of this article, the part of the urban area that does not fall within the urban center will be called the suburban ring. The boundaries of these urban areas, defined in terms of work activity, are not fixed and can evolve over time. The division applied is, therefore, that of 2010. The urban ring and the suburban ring are grouped in the "periphery", as opposed to the central town.

Our study focuses on 113 urban areas (Figure 1). The study area as a whole encompasses 12.8 million inhabitants, 4.7 million of whom live in a central town and 3.8 million in the suburban ring, representing in total 19\% of the population of metropolitan France. These inhabitants hold 5 million jobs across this territory, 2.7 million of them in the central towns, 1.5 million in the rest of the urban area, i.e., $16 \%$ of total jobs across metropolitan France. In 2006, 4.3 million workers resided in the study area and 1.3 million were surveyed in the census, compared with 4.55 million in 2016, 1.3 million of whom were surveyed. 


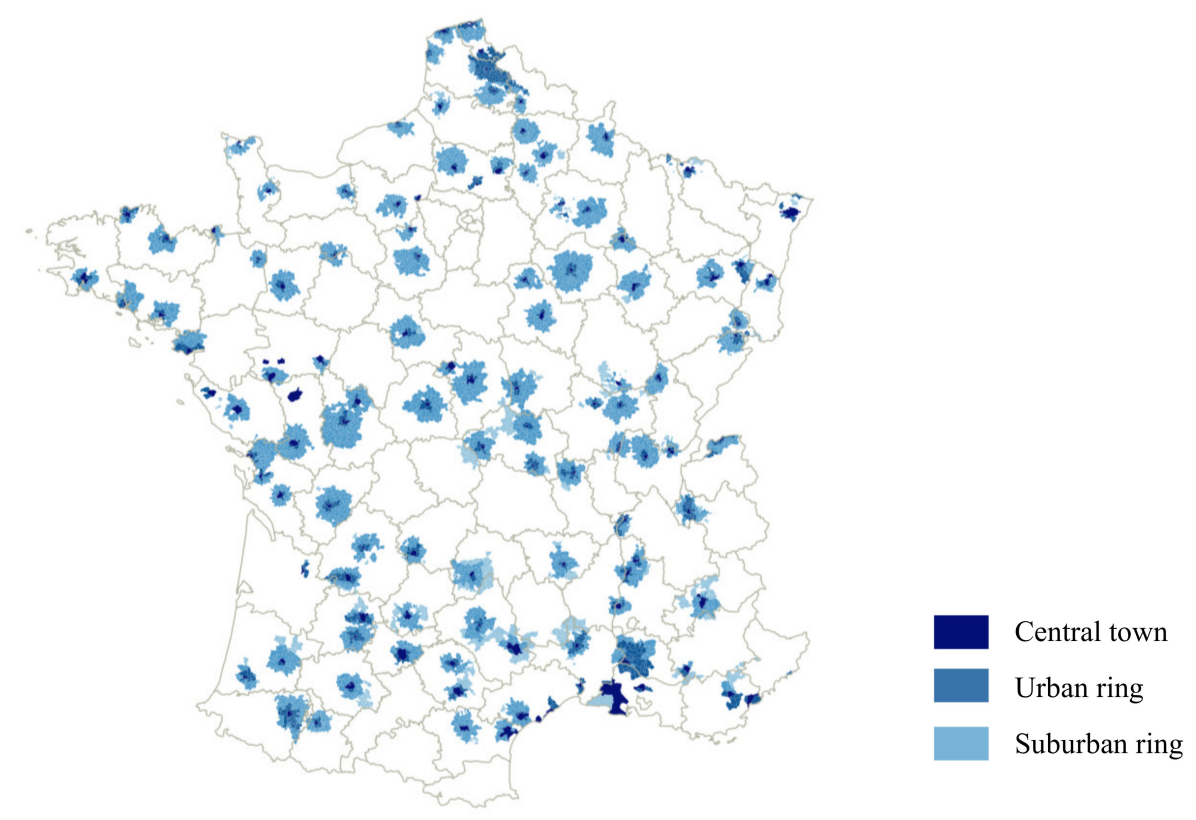

Figure 1. Selected mid-sized French cities with their urban area.

\subsection{Characterization of Revitalization}

We do not know what the potential impact may be of a revitalization process for mid-sized cities in France, nor what specific form it will take. However, the literature helps us to predict what a possible revitalization of these city centers could look like. The first meaning of revitalization is a change in population trajectory after shrinkage. Since the most common definition of shrinkage is a decrease in population, our first indicator is the change in total population. In France, revitalization is often synonymous with a densification of the urban ring close to the city center [28]. This phenomenon is frequently associated with gentrification $[17,29]$, the substitution of the existing population by a more highly educated population. Population renewal is generally reflected by an increase in the proportion of executives in the active population. Trajectories of mid-sized cities are currently heading towards an increase in the unemployment rate among the active population, a loss in the number of inhabitants, commercial desertification and an increase in the number of vacant housing units [30]. It can, therefore, be assumed that the objective of revitalizing centers is to reverse the trajectory of these shrinking centers [31]. The indicators selected thus correspond to a selection of indicators that correspond to the criteria of many urban renewal or revitalization policies [32]. They also directly or indirectly modify commuting distances and the main commuting modes. The following six indicators chosen to characterize revitalization correspond to a rate of change between 2006 and 2016 and are available in the French census:

(i) Total population;

(ii) Share of working people between 15 and 64 years of age in the population between 15 and 64 years of age;

(iii) Share of unemployment people between 15 and 64 years old among the total population between 15 and 64 years old;

(iv) Number of jobs per 100 employees;

(v) Number of executives per 100 employees;

(vi) Number of vacant units out of the total number of units.

\section{3. $\mathrm{CO}_{2}$ Emissions from Commuting Trips}

To evaluate mobility behavior in each city, the data used come from the INSEE survey on commuting from 2006 and 2016. The table includes a sample of working-age people. 
For each working-age person of 15 or above, the municipality of residence and the job, the method of travel (modal choice?), as well as the different sociodemographic characteristics of the individual and his or her household are available. As suggested by other research [33], a maximum threshold of $200 \mathrm{~km}$ for commuting distances was applied in order to limit anomalous values in the survey. The "Metric" distance calculator designed by INSEE allows an estimate of commuting distances to be traveled using the French road network. This tool uses map collections provided by the national geographical institute (IGN) to find out the nature of the road segments, their length, their slope and bends, as well as information on density. The instrument's supra-municipal scale is thus used to estimate the distances between the center of gravity of the municipality in which people live and the primary center of the municipality in which they work. For people who live and work in the same municipality, the distance provided by the calculator is zero. In this study, its value was estimated as the length of the municipality's hypothetical radius, taking the latter to form a circle. The distances assessed by the Metric calculator were compared with the straight-line distance between the centers of gravity of the municipalities where people work and where they live, again taking the radius of the municipality in the case of intra-municipal journeys. The mean value of the commuting distance of all the workers in the territory corresponds to 1.25 times the straight-line distance with a quasi-linear relationship.

Census data also indicate the main commuting mode. This allows us to determine the car modal share for commuting. It is assumed that the chosen working place is that reported in the census. In order to specify the distances actually traveled, additional data were used. Data from 12 household travel surveys in mid-sized cities were used to calculate coefficients to adjust the number of commuting loops (1.23), the share of working drivers among those who make the trip by car $(94.7 \%)$ and the share of working people who have worked the day before (91.6\%). This share takes into account teleworking, but is constant and does not depend on the distance to the workplace, which is a key factor in the rate of teleworkers [34]. Due to the lack of data on each of the mid-sized cities in the study, these average values were applied to all the cities studied. The daily commuting distance d_d is, therefore, d_d = 2.(0.947).(0.916).(1.23).d_w, d_w defined as the commuting distance using the method of Bouzouina et al. [35]. Only the distances traveled by car were evaluated. This mode of transport is the most $\mathrm{CO}_{2}$-emitting mode for daily journeys. The $2008 \mathrm{National}$ Transportation and Travel Survey attributed $96 \%$ of $\mathrm{CO}_{2}$ emissions to cars used for daily mobility. Every year, the French Environment and Energy Management Agency (ADEME) estimates the carbon footprint, i.e., the direct $\mathrm{CO}_{2}$ equivalent-emissions for a one-kilometer trip with an average French vehicle. In 2006, the average value was $181 \mathrm{~g} / \mathrm{km}$ of $\mathrm{CO}_{2}$ eq. In 2016, the emissions were reduced to $163 \mathrm{~g} / \mathrm{km}$.

\subsection{Statistical Models}

To analyze the impact of the various revitalization indicators for the central city on $\mathrm{CO}_{2}$ emissions due to commuting, statistical models were applied to the data. In order to get an estimate of the general trends of these environmental impacts, the distances traveled by car and their modal share were analyzed through the different characteristics of the central city. It is possible to compare these two values between 2006 and 2016, as they remained homogeneous. The distribution of age, gender, and the proportion of socio-professional categories are equivalent. A model applied to a sample from both census years can thus be consistent.

A linear regression model was applied to the commuting distances of each worker who uses a car as his or her main mode of transport. The distances and car modal shares were expressed according to the characteristics of the workers (gender, socio-professional category, type of work contract, type of housing and household status). Changes in population characteristics are not independent of revitalization variables. Therefore, we chose to add these variables to the model so that the revitalization variables could be analyzed independently of changes in the population structure. The interaction effect 
of each indicator with the year of the census (2006 or 2016) and the area of residence highlighted the impact of the indicator on different types of residence and showed whether the magnitude of the impact changed over these 10 years. The logarithm of the commuting distance $(D)$ was then expressed according to different qualitative and quantitative sociodemographic explanatory variables $X_{i}, i \in N$ [36]. The revitalization variables $Z_{j}, j \in J$, the year $Y$, and the urban type $U$ were added to the models. The interaction effects of key nonindependent variables (the revitalization variable, the year, and the urban type) were also included in the different models, with $\mathrm{M}$ as the set of all interaction effects between these variables. The coefficients $\left(\beta_{i}, \partial_{j}, \rho_{j}, \sigma_{j}, \tau_{i}\right)$ were calculated from the following reference situation: a woman from a dual-income household with one child living in the suburban ring in 2006.

$$
\ln (D)=\beta_{0}+\sum_{i \in N} \beta_{i} X_{i}+\partial_{j} Z_{j}+\rho_{j} Y+\sigma_{j} U+\sum_{k \in M} \tau_{i} Z_{j k}, Y_{k}, U_{k}, j \in J
$$

The probability of a worker using his or her car was estimated by a logit model considering the same explanatory variables, those specific to the individual and the interaction effects of the year, the place of residence and the indicator. The aim was to estimate the probability of a worker commuting by car. A binomial logit model was then constructed, the variable to be explained as 1 if the worker uses the car most often, 0 otherwise. Probability $P$ was then calculated as:

$$
P=\frac{1}{1+e^{\sum_{i \in N} \beta_{i} X_{i}+\partial_{j} Z_{j}+\rho_{j} Y+\sigma_{j} U+\sum_{k \in M} \tau_{i} Z_{j k}, Y_{k}, U_{k}}}
$$

\section{Presentation of Mid-Sized Cities and Mobility Behavior of Their Residents}

\subsection{A Relative Decline in the Attractiveness of Mid-Sized Cities since 2006}

In 2016, two vitality indicators highlighted the economic difficulty and low attractiveness of the centers of mid-sized French cities. The unemployment rate per worker was double the national average of $10 \%$, and the housing vacancy rate was $11 \%$ ( $8 \%$ in France). On average, among the 113 cities considered in the study, central cities have lost $3 \%$ of their jobs and $6 \%$ of their workers. In addition, there has been a significant increase in the unemployment rate, which has risen from $15 \%$ to $20 \%$ in ten years, while in France, the share has risen from $8.7 \%$ to $9.8 \%$. This unemployment rate must be related to population changes. If the population decreases, the unemployed who tend to stay will be over-represented. However, the correlation coefficient between both indicators in the cities studied is very low, which implies that unemployment dynamics are not very closely linked to population growth. The vacancy rate follows the same trend, rising from $8 \%$ in 2006 to nearly $12 \%$ in 2016, with a much faster increase (nearly 50\%) than the national average. As the rate of new housing in these cities is low, this increase in vacancy reflects the significant decline in the attractiveness of central communities in mid-sized cities [37].

However, when considering the average of all urban areas, different conclusions emerge. The total number of jobs appears stable $(-1 \%)$ as does the number of workers. Unemployment in the urban area has also increased but remains lower than in the central city, rising from $12 \%$ to $15 \%$ in ten years. In total, $35 \%$ of cities gained jobs in the central city and $44 \%$ in the entire urban area. The pattern is the same for the number of working people, with $74 \%$ of centers losing workers and only $40 \%$ of peripheries. If the trend of job losses in cities is identical to that of their centers, this is not the case for the active population, with $35 \%$ of cities having a central town that lost workers and a periphery that gained workers. Only one city gained workers in the central town and lost some in the periphery. While the definition of a shrinking city is a net loss of population, most mid-sized cities are not considered as shrinking because the urban population has continued to increase for most of them $[4,14]$.

The conclusions are also moderate when the 113 mid-sized cities are considered separately. Cities that lose jobs are also those that lose workers. However, when looking 
at the number of jobs relative to the number of working people, in most cities, the loss of working people is greater than the loss of jobs, which means that the employment rate per working person is increasing in many central towns. Figure $2 \mathrm{a}-\mathrm{f}$ show the evolution of mid-sized cities between 2006 and 2016 according to the selected revitalization indicators. We also added to the color graphs the average $\mathrm{CO}_{2}$ emissions per worker for each mid-sized city. The size of the circle depicts the distance to the nearest metropolis in Figure 2a and the population of the urban area in the other figures.
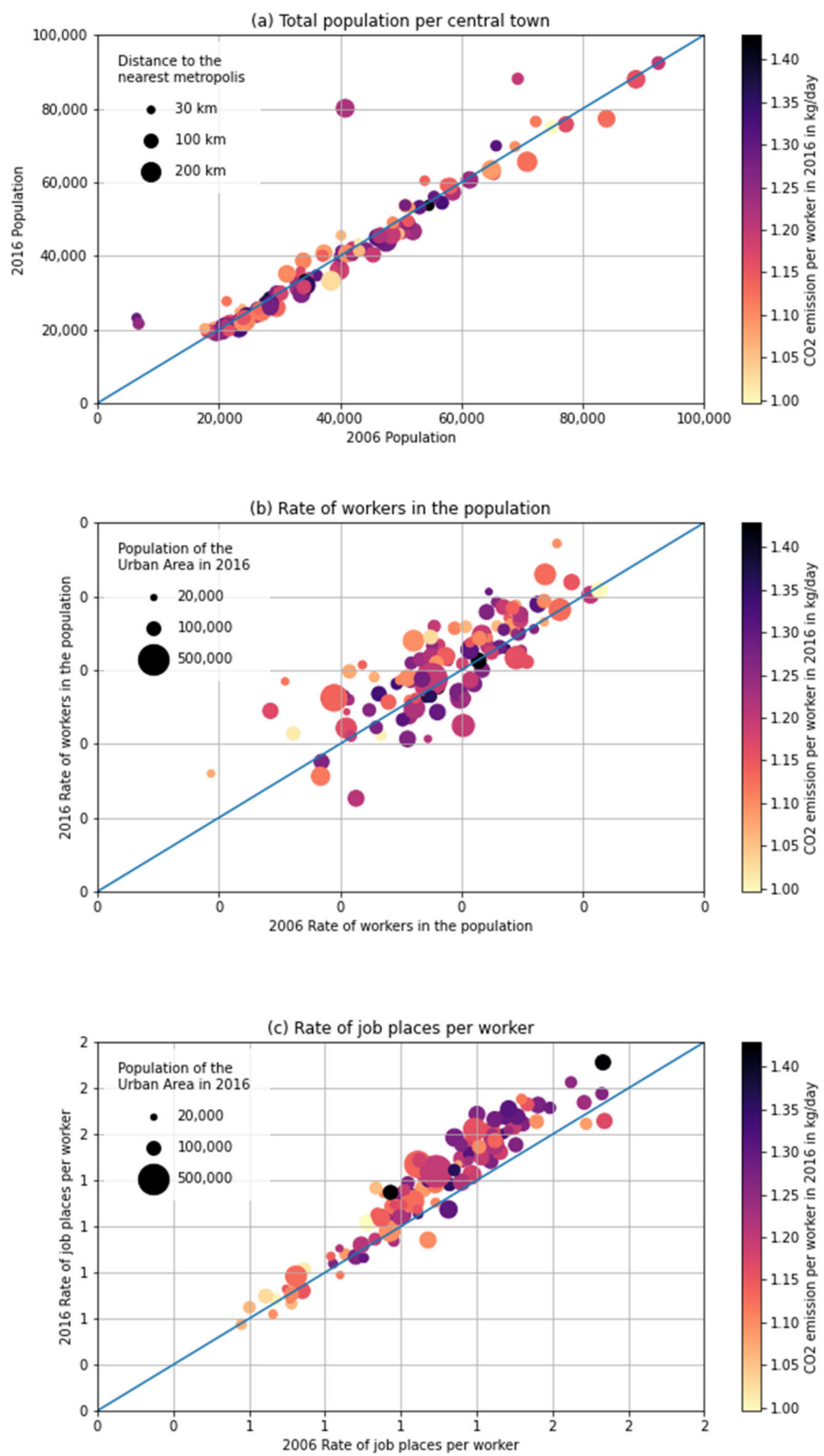

Figure 2. Cont. 

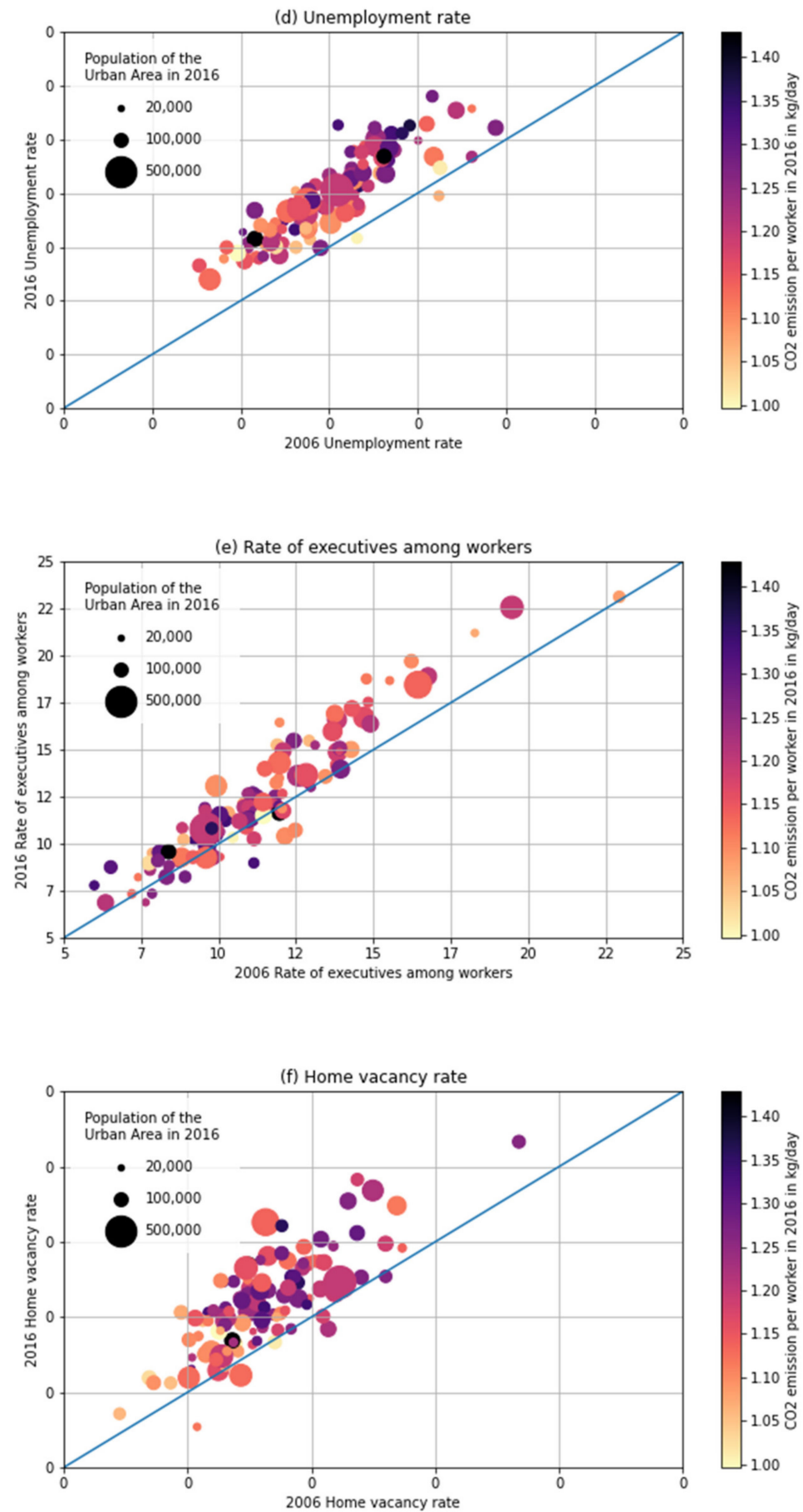

Figure 2. Evolution of the various indicators studied between 2006 and 2016 for the 113 French mid-sized cities. (a) Population by central town. (b) Rate of workers among the population. (c) Employment rate per worker. (d) Unemployment rate. (e) Rate of executives among workers. (f) Vacancy rate for housing.

As shown in Figure 2c, only 15 cities have a declining employment to working population ratio. These figures show the evolution of the average indicators for each of the mid-sized cities studied between 2006 and 2016. The slope indicates the status quo reference.

Thus, on the one hand, only 4 central cities have an unemployment rate that has declined in relation to the national trajectory, and $57 \%$ of central cities have seen an increase of more than $40 \%$ in housing vacancy over 10 years, while only 5 cities have seen a decrease 
(Figure 2d,f). On the other hand, some indicators illustrate a certain dynamism. While the total population has increased by only $15 \%$ in mid-sized cities, $25 \%$ have experienced an increase in both working population and number of executives that is above the national average (Figure 2a,b,e). The surface area of the central city and its evolution have no obvious link with the $\mathrm{CO}_{2}$ emissions of the workers. There is also no obvious link between the population of the urban area or other indicators of revitalization and the $\mathrm{CO}_{2}$ emissions of workers. Figure $2 \mathrm{c}$ clearly shows that cities with the lowest rate of job places per worker are associated with the lowest $\mathrm{CO}_{2}$ emissions per worker. Statistical models are, therefore, indispensable to go further in the analysis.

\subsection{Increase in $\mathrm{CO}_{2}$ Emissions from Commuting since 2006}

Mobility behavior in mid-sized cities is characterized by a strong dominance of private car use. In 2016, the modal share of private cars for commuting trips was more than $80 \%$. The average commuting distance of drivers was $13.7 \mathrm{~km}$. In the center of mid-sized cities, $68 \%$ of working residents work in the center, with only $20 \%$ in the suburban ring. However, those who travel the longest distances are evenly distributed among the different urban contexts, with $6 \%$ of the working population living more than $40 \mathrm{~km}$ away from their workplace. Between 2006 and 2016, the car modal share increased by $3.6 \%$, with a stagnation of $71 \%$ in the central town and a consolidation of the greater distance from the center with an increase of $4.5 \%$, reaching $89 \%$ in the suburban ring in 2016. Distances traveled by car increased even more sharply between 2006 and 2016 throughout the study area. The commuting distance for working people living in the study area and using a car was $10.8 \mathrm{~km}$ in 2006 , rising to $13.7 \mathrm{~km}$ in 2016 .

The gap has widened more in suburban rings of municipalities, where the average travel distance is $26 \%$ greater than in the mid-sized city centers. The number of workers also increased the most in these areas, and carbon emissions increased accordingly. We calculated a $40 \%$ increase in the total distances potentially traveled by all active people if $91 \%$ go to work (percentage explained previously). Despite technological progress enabling the reduction in carbon quantities emitted, $\mathrm{CO}_{2}$ emissions per worker in the territory have increased from $1.55 \mathrm{~kg}$ to $1.83 \mathrm{~kg}$ per home-work trip. We then obtained the potential daily $\mathrm{CO}_{2}$ emissions related to commuting trips per worker: $3.98 \mathrm{~kg}$ of $\mathrm{CO}_{2}$ in 2006 and $4.69 \mathrm{~kg}$ in 2016, i.e., an $18 \%$ increase. The average gap between residents of the mid-sized city and the suburban ring decreased from 70\% in 2006 to $54 \%$ in 2016.

Figure 3 confirms that all the mid-sized cities studied have experienced an increase in car use in their urban area. No obvious link between workers' $\mathrm{CO}_{2}$ emissions or their evolution and the surface area of urban areas in mid-sized cities or the distance to the nearest metropolis emerges from Figure 3. It remains to be investigated whether this increase is partly explained by changes in the urban characteristics of the central city between 2006 and 2016. 


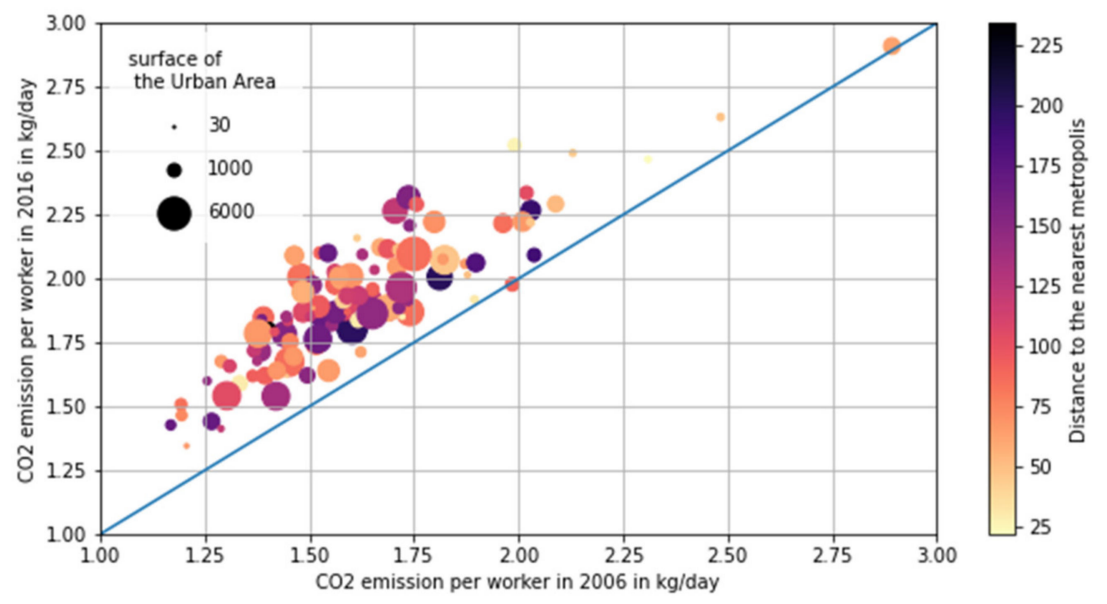

Figure 3. Comparison of $\mathrm{CO}_{2}$ emissions per worker in the 113 urban areas in 2006 and 2016

\section{Impact of the Change in Attractiveness of the Central City between 2006 and 2016}

Further analysis serves to isolate indicators of the city's economic and urban dynamics from the socio-demographic characteristics of its residents. Tables 1 and 2 show the results of the models for the 2006 and 2016 censuses simultaneously. Table 1 explains the distances traveled by private car users for commuting with linear models, and Table 2 explains the modal share of private cars for this trip with logit models as described in part 2.4. The revitalization indicators were tested in separate models because, as we saw in the previous section, they are not necessarily correlated. Indeed, only the changes in the rate of workers and the number of jobs per worker in the central city are slightly correlated $\left(R^{2}=0.16\right)$. This means that the evolution of one indicator in one direction or the other does not drive the other indicators focused on the central city level along with it. This was confirmed by Wolff et al. [14], who categorized the processes of decline of mid-sized cities in France. The impact of each indicator on mobility must, therefore, be analyzed independently. Our hypothesis can be formulated as follows: "The revitalization of the city center implies a concentration of activities and workers and thus a decrease in car use".

Table 1. Private car distance models for commuting.

\begin{tabular}{|c|c|c|c|c|c|c|}
\hline & Population & $\begin{array}{c}\text { Jobs-Housing } \\
\text { Ratio }\end{array}$ & $\begin{array}{c}\text { Dwelling } \\
\text { Vacancy Rate }\end{array}$ & Worker Rate & $\begin{array}{c}\text { Unemployment } \\
\text { Rate }\end{array}$ & Executive Rate \\
\hline (Intercept) & $\begin{array}{c}1.88^{* * *} \\
\left(4.5 \times 10^{-3}\right)\end{array}$ & $\begin{array}{c}2.15^{* * *} \\
\left(1.4 \times 10^{-2}\right)\end{array}$ & $\begin{array}{c}2.30 * * * \\
\left(6.3 \times 10^{-3}\right)\end{array}$ & $\begin{array}{c}2.64^{* * *} \\
\left(3.7 \times 10^{-2}\right)\end{array}$ & $\begin{array}{c}2.34^{* * *} \\
\left(8.5 \times 10^{-3}\right)\end{array}$ & $\begin{array}{c}2.2^{* * *} \\
\left(8.2 \times 10^{-3}\right)\end{array}$ \\
\hline \multicolumn{7}{|l|}{ Full-time work } \\
\hline $\begin{array}{l}\text { Partial-time } \\
\text { work }\end{array}$ & $\begin{array}{c}-0.12^{* * *} \\
\left(1.8 \times 10^{-3}\right)\end{array}$ & $\begin{array}{c}-0.12^{* * *} \\
\left(1.8 \times 10^{-3}\right)\end{array}$ & $\begin{array}{c}-0.12^{* * *} \\
\left(1.8 \times 10^{-3}\right)\end{array}$ & $\begin{array}{c}-0.12^{* * *} \\
\left(1.8 \times 10^{-3}\right)\end{array}$ & $\begin{array}{c}-0.12^{* * *} \\
\left(1.8 \times 10^{-3}\right)\end{array}$ & $\begin{array}{c}-0.12^{* * *} \\
\left(1.8 \times 10^{-3}\right)\end{array}$ \\
\hline \multicolumn{7}{|l|}{ Employee } \\
\hline $\begin{array}{l}\text { Executive and } \\
\text { intellectual } \\
\text { function }\end{array}$ & $\begin{array}{c}0.24^{* * *} \\
\left(2.3 \times 10^{-3}\right)\end{array}$ & $\begin{array}{c}0.25^{* * *} \\
\left(2.3 \times 10^{-3}\right)\end{array}$ & $\begin{array}{c}0.24^{* * *} \\
\left(2.3 \times 10^{-3}\right)\end{array}$ & $\begin{array}{c}0.24^{* * *} \\
\left(2.3 \times 10^{-3}\right)\end{array}$ & $\begin{array}{c}0.24^{* * *} \\
\left(2.3 \times 10^{-3}\right)\end{array}$ & $\begin{array}{c}0.24^{* * *} \\
\left(2.3 \times 10^{-3}\right)\end{array}$ \\
\hline Labor & $\begin{array}{c}0.07^{* * *} \\
\left(1.9 \times 10^{-3}\right)\end{array}$ & $\begin{array}{c}0.07^{* * *} \\
\left(1.9 \times 10^{-3}\right)\end{array}$ & $\begin{array}{c}0.07^{* * *} \\
\left(1.9 \times 10^{-3}\right)\end{array}$ & $\begin{array}{c}0.07^{* * *} \\
\left(1.9 \times 10^{-3}\right)\end{array}$ & $\begin{array}{c}0.07^{* * *} \\
\left(1.9 \times 10^{-3}\right)\end{array}$ & $\begin{array}{c}0.07^{* * *} \\
\left(1.9 \times 10^{-3}\right)\end{array}$ \\
\hline
\end{tabular}


Table 1. Cont.

\begin{tabular}{|c|c|c|c|c|c|c|}
\hline & Population & $\begin{array}{c}\text { Jobs-Housing } \\
\text { Ratio }\end{array}$ & $\begin{array}{c}\text { Dwelling } \\
\text { Vacancy Rate }\end{array}$ & Worker Rate & $\begin{array}{c}\text { Unemployment } \\
\text { Rate }\end{array}$ & Executive Rate \\
\hline \multicolumn{7}{|l|}{$\begin{array}{l}\text { Family composed } \\
\text { of a couple of two } \\
\text { workers }\end{array}$} \\
\hline Single parent & $\begin{array}{c}-0.11^{* * *} \\
\left(3.1 \times 10^{-3}\right)\end{array}$ & $\begin{array}{c}-0.10^{* * *} \\
\left(3.1 \times 10^{-3}\right)\end{array}$ & $\begin{array}{c}-0.11^{* * *} \\
\left(3.1 \times 10^{-3}\right)\end{array}$ & $\begin{array}{c}-0.12^{* * *} \\
\left(3.1 \times 10^{-3}\right)\end{array}$ & $\begin{array}{c}-0.12^{* * *} \\
\left(3.1 \times 10^{-3}\right)\end{array}$ & $\begin{array}{c}-0.12^{* * *} \\
\left(3.1 \times 10^{-3}\right)\end{array}$ \\
\hline $\begin{array}{c}\text { Family with } \\
\text { one parent and } \\
\text { children }\end{array}$ & $\begin{array}{c}-0.08^{* * *} \\
\left(5.2 \times 10^{-3}\right)\end{array}$ & $\begin{array}{c}-0.08^{* * *} \\
\left(5.2 \times 10^{-3}\right)\end{array}$ & $\begin{array}{c}-0.08^{* * *} \\
\left(5.2 \times 10^{-3}\right)\end{array}$ & $\begin{array}{c}-0.08^{* * *} \\
\left(5.2 \times 10^{-3}\right)\end{array}$ & $\begin{array}{c}-0.08^{* * *} \\
\left(5.2 \times 10^{-3}\right)\end{array}$ & $\begin{array}{c}-0.08^{* * *} \\
\left(5.2 \times 10^{-3}\right)\end{array}$ \\
\hline $\begin{array}{c}\text { Family } \\
\text { composed of a } \\
\text { couple with } \\
\text { only one } \\
\text { worker }\end{array}$ & $\begin{array}{l}-0.10^{* * *} \\
\left(3 \times 10^{-3}\right)\end{array}$ & $\begin{array}{l}-0.10^{* * *} \\
\left(3 \times 10^{-3}\right)\end{array}$ & $\begin{array}{l}-0.10^{* * *} \\
\left(3 \times 10^{-3}\right)\end{array}$ & $\begin{array}{l}-0.10^{* * *} \\
\left(3 \times 10^{-3}\right)\end{array}$ & $\begin{array}{l}-0.10^{* * *} \\
\left(3 \times 10^{-3}\right)\end{array}$ & $\begin{array}{c}-0.10^{* * *} \\
\left(3 \times 10^{-3}\right)\end{array}$ \\
\hline \multicolumn{7}{|l|}{ House } \\
\hline Apartment & $\begin{array}{c}-0.05^{* * *} \\
\left(1.7 \times 10^{-3}\right)\end{array}$ & $\begin{array}{c}-0.05^{* * *} \\
\left(1.7 \times 10^{-3}\right)\end{array}$ & $\begin{array}{c}-0.05^{* * *} \\
\left(1.7 \times 10^{-3}\right)\end{array}$ & $\begin{array}{c}-0.04^{* * *} \\
\left(1.7 \times 10^{-3}\right)\end{array}$ & $\begin{array}{c}-0.05^{* * *} \\
\left(1.7 \times 10^{-3}\right)\end{array}$ & $\begin{array}{c}-0.05^{* * *} \\
\left(1.7 \times 10^{-3}\right)\end{array}$ \\
\hline \multicolumn{7}{|l|}{$\begin{array}{l}\text { No limit jobs. } \\
\text { Public service } \\
\text { worker }\end{array}$} \\
\hline $\begin{array}{l}\text { Placed by a } \\
\text { temporary } \\
\text { employment } \\
\text { agency }\end{array}$ & $\begin{array}{c}0.07^{* * *} \\
\left(4.5 \times 10^{-3}\right)\end{array}$ & $\begin{array}{c}0.07^{* * *} \\
\left(4.5 \times 10^{-3}\right)\end{array}$ & $\begin{array}{c}0.07^{* * *} \\
\left(4.5 \times 10^{-3}\right)\end{array}$ & $\begin{array}{c}0.07^{* * *} \\
\left(4.5 \times 10^{-3}\right)\end{array}$ & $\begin{array}{c}0.07^{* * *} \\
\left(4.5 \times 10^{-3}\right)\end{array}$ & $\begin{array}{c}0.07^{* * *} \\
\left(4.5 \times 10^{-3}\right)\end{array}$ \\
\hline \multicolumn{7}{|l|}{ Female } \\
\hline Male & $\begin{array}{c}0.10^{* * *} \\
\left(1.7 \times 10^{-3}\right)\end{array}$ & $\begin{array}{c}0.10^{* * *} \\
\left(1.7 \times 10^{-3}\right)\end{array}$ & $\begin{array}{c}0.10^{* * *} \\
\left(1.7 \times 10^{-3}\right)\end{array}$ & $\begin{array}{c}0.10^{* * *} \\
\left(1.7 \times 10^{-3}\right)\end{array}$ & $\begin{array}{c}0.10^{* * *} \\
\left(1.7 \times 10^{-3}\right)\end{array}$ & $\begin{array}{c}0.10^{* * *} \\
\left(1.7 \times 10^{-3}\right)\end{array}$ \\
\hline \multicolumn{7}{|l|}{2006} \\
\hline 2016 & $\begin{array}{c}0.19^{* * *} \\
\left(5.5 \times 10^{-3}\right)\end{array}$ & $\begin{array}{c}0.24^{* * *} \\
\left(1.3 \times 10^{-3}\right)\end{array}$ & $\begin{array}{c}0.16^{* * *} \\
\left(8.3 \times 10^{-3}\right)\end{array}$ & $\begin{array}{c}0.10^{* *} \\
\left(4.9 \times 10^{-2}\right)\end{array}$ & $\begin{array}{c}0.12^{* * *} \\
\left(1.2 \times 10^{-2}\right)\end{array}$ & $\begin{array}{c}0.15^{* * *} \\
\left(1.4 \times 10^{-2}\right)\end{array}$ \\
\hline \multicolumn{7}{|l|}{ Suburban ring } \\
\hline Urban ring & $\begin{array}{c}-0.46^{* * *} \\
\left(6.1 \times 10^{-3}\right)\end{array}$ & $\begin{array}{c}-0.46^{* * *} \\
\left(1.6 \times 10^{-2}\right)\end{array}$ & $\begin{array}{c}-0.49^{* * *} \\
\left(8.3 \times 10^{-3}\right)\end{array}$ & $\begin{array}{c}1.15^{* * *} \\
\left(4.8 \times 10^{-2}\right)\end{array}$ & $\begin{array}{c}-0.87^{* * *} \\
\left(1.1 \times 10^{-2}\right)\end{array}$ & $\begin{array}{c}-0.33^{* * *} \\
\left(1.3 \times 10^{-2}\right)\end{array}$ \\
\hline Center town & $\begin{array}{c}-0.58^{* * *} \\
\left(5.7 \times 10^{-3}\right)\end{array}$ & $\begin{array}{c}0.30^{* * *} \\
\left(1.7 \times 10^{-2}\right)\end{array}$ & $\begin{array}{c}-0.25^{* * *} \\
\left(8.3 \times 10^{-3}\right)\end{array}$ & $\begin{array}{c}-0.95^{* * *} \\
\left(5.2 \times 10^{-2}\right)\end{array}$ & $\begin{array}{c}-0.43^{* * *} \\
\left(1.1 \times 10^{-2}\right)\end{array}$ & $\begin{array}{c}-1.19^{* * *} \\
\left(1.3 \times 10^{-2}\right)\end{array}$ \\
\hline Indicator & · & $\cdot$ & $\begin{array}{c}-1.10^{* * *} \\
\left(7.2 \times 10^{-2}\right)\end{array}$ & $\begin{array}{c}-0.62^{* * *} \\
\left(5.3 \times 10^{-2}\right)\end{array}$ & $\begin{array}{c}-0.84^{* * *} \\
\left(5.5 \times 10^{-2}\right)\end{array}$ & - \\
\hline $\begin{array}{l}\text { Indicator * } \\
\text { Urban ring }\end{array}$ & $\begin{array}{c}1.6 \times 10^{-6 * * *} \\
\left(1.4 \times 10^{-7}\right)\end{array}$ & $\cdot$ & $\begin{array}{c}1.00 * * * \\
\left(9.8 \times 10^{-2}\right)\end{array}$ & $\begin{array}{c}-2.30^{* * *} \\
\left(7.0 \times 10^{-2}\right)\end{array}$ & $\begin{array}{c}2.9^{* * *} \\
\left(7.3 \times 10^{-2}\right)\end{array}$ & $\begin{array}{c}-0.13^{* * *} \\
\left(2.0 \times 10^{-2}\right)\end{array}$ \\
\hline $\begin{array}{l}\text { Indicator }{ }^{*} \\
\text { Center town }\end{array}$ & $\begin{array}{c}2.6 \times 10^{-6 * * *} \\
\left(1.2 \times 10^{-7}\right)\end{array}$ & $\begin{array}{c}-0.6^{* * *} \\
\left(1.1 \times 10^{-2}\right)\end{array}$ & $\begin{array}{c}-3.05^{* * *} \\
\left(1.0 \times 10^{-1}\right)\end{array}$ & $\begin{array}{c}0.65^{* * *} \\
\left(7.5 \times 10^{-2}\right)\end{array}$ & $\begin{array}{c}-0.4^{* * *} \\
\left(7.3 \times 10^{-2}\right)\end{array}$ & $\begin{array}{c}-1.04^{* * *} \\
\left(2.0 \times 10^{-2}\right)\end{array}$ \\
\hline Indicator * 2016 & . & . & $\begin{array}{c}0.38^{* * *} \\
\left(8.7 \times 10^{-2}\right)\end{array}$ & - & $\begin{array}{c}0.4^{* * *} \\
\left(7.0 \times 10^{-2}\right)\end{array}$ & \\
\hline $\begin{array}{c}\text { Urban ring * } \\
2016\end{array}$ & - & $\begin{array}{c}0.10^{* * *} \\
\left(2.1 \times 10^{-2}\right)\end{array}$ & · & $\begin{array}{c}-0.66^{* * *} \\
\left(6.7 \times 10^{-2}\right)\end{array}$ & . & . \\
\hline $\begin{array}{l}\text { Center town * } \\
2016\end{array}$ & $\begin{array}{c}-0.1^{* * *} \\
\left(7.9 \times 10^{-3}\right)\end{array}$ & $\begin{array}{c}-0.25^{* * *} \\
\left(2.1 \times 10^{-2}\right)\end{array}$ & $\cdot$ & $\begin{array}{c}-0.89^{* * *} \\
\left(7.0 \times 10^{-2}\right)\end{array}$ & $\begin{array}{c}0.26^{* * *} \\
\left(1.7 \times 10^{-2}\right)\end{array}$ & $\begin{array}{c}0.16^{* * *} \\
\left(1.7 \times 10^{-2}\right)\end{array}$ \\
\hline
\end{tabular}


Table 1. Cont

\begin{tabular}{|c|c|c|c|c|c|c|}
\hline & Population & $\begin{array}{c}\text { Jobs-Housing } \\
\text { Ratio }\end{array}$ & $\begin{array}{c}\text { Dwelling } \\
\text { Vacancy Rate }\end{array}$ & Worker Rate & $\begin{array}{c}\text { Unemployment } \\
\text { Rate }\end{array}$ & Executive Rate \\
\hline $\begin{array}{l}\text { Indicator * } \\
\text { Urban ring * } \\
2016\end{array}$ & - & . & - & $\begin{array}{c}1.03^{* * *} \\
\left(9.7 \times 10^{-2}\right)\end{array}$ & $\begin{array}{c}-1.08^{* * *} \\
\left(9.3 \times 10^{-2}\right)\end{array}$ & - \\
\hline $\begin{array}{l}\text { Indicator * } \\
\text { Center town * } \\
2016\end{array}$ & $\begin{array}{c}1.1 \times 10^{-6 * * *} \\
\left(1.7 \times 10^{-7}\right)\end{array}$ & $\begin{array}{c}0.14^{* * *} \\
\left(1.5 \times 10^{-2}\right)\end{array}$ & $\begin{array}{c}0.71^{* * *} \\
\left(1.2 \times 10^{-1}\right)\end{array}$ & $\begin{array}{c}1.18^{* * *} \\
\left(1.0 \times 10^{-1}\right)\end{array}$ & $\begin{array}{c}-1.57^{* * *} \\
\left(9.5 \times 10^{-2}\right)\end{array}$ & $\begin{array}{c}-0.33^{* * *} \\
\left(2.6 \times 10^{-2}\right)\end{array}$ \\
\hline Adjusted $\mathrm{R}^{2}$ & 0.111 & 0.114 & 0.113 & 0.112 & 0.113 & 0.116 \\
\hline
\end{tabular}

*** $p<0.001 ;{ }^{* *} p<0.01 ; * p<0.05$. "-“: not statistically significant or confidence interval not totally positive or negative at $95 \%$. ".": the estimated parameter has a negligible effect on the explained variable; value under bracket (standard error); the attributes in italics are the reference attributes.

Table 2. Logit models of modal share of car for commuting.

\begin{tabular}{|c|c|c|c|c|c|c|}
\hline & Population & $\begin{array}{c}\text { Jobs-Housing } \\
\text { Ratio }\end{array}$ & $\begin{array}{c}\text { Dwelling } \\
\text { Vacancy Rate }\end{array}$ & Worker Rate & $\begin{array}{l}\text { Unemployment } \\
\text { Rate }\end{array}$ & Executive Rate \\
\hline (Intercept) & $\begin{array}{c}1.89^{* * *} \\
\left(1.4 \times 10^{-2}\right)\end{array}$ & $\begin{array}{c}1.38^{* * *} \\
\left(1.2 \times 10^{-2}\right)\end{array}$ & $\begin{array}{c}1.86^{* * *} \\
\left(8.2 \times 10^{-3}\right)\end{array}$ & $\begin{array}{c}2.21^{* * *} \\
\left(3.6 \times 10^{-2}\right)\end{array}$ & $\begin{array}{c}2.14^{* * *} \\
\left(9.7 \times 10^{-3}\right)\end{array}$ & $\begin{array}{c}1.76^{* * *} \\
\left(9.5 \times 10^{-3}\right)\end{array}$ \\
\hline \multicolumn{7}{|l|}{ Full-time work } \\
\hline $\begin{array}{l}\text { Partial-time } \\
\text { work }\end{array}$ & $\begin{array}{l}-0.26^{* * *} \\
\left(4 \times 10^{-3}\right) \\
\end{array}$ & $\begin{array}{c}-0.25^{* * *} \\
\left(4 \times 10^{-3}\right)\end{array}$ & $\begin{array}{c}-0.25^{* * *} \\
\left(4 \times 10^{-3}\right) \\
\end{array}$ & $\begin{array}{c}-0.25^{* * *} \\
\left(4 \times 10^{-3}\right) \\
\end{array}$ & $\begin{array}{c}-0.25^{* * *} \\
\left(4 \times 10^{-3}\right) \\
\end{array}$ & $\begin{array}{c}-0.25^{* * *} \\
\left(4 \times 10^{-3}\right) \\
\end{array}$ \\
\hline \multicolumn{7}{|l|}{ Employee } \\
\hline $\begin{array}{l}\text { Intermediary } \\
\text { businesses, } \\
\text { senior } \\
\text { executives }\end{array}$ & $\begin{array}{c}0.39 * * * \\
\left(1.2 \times 10^{-2}\right)\end{array}$ & $\begin{array}{c}0.37^{* * *} \\
\left(1.2 \times 10^{-2}\right)\end{array}$ & $\begin{array}{c}0.37^{* * *} \\
\left(1.2 \times 10^{-2}\right)\end{array}$ & $\begin{array}{c}0.38^{* * *} \\
\left(1.2 \times 10^{-2}\right)\end{array}$ & $\begin{array}{c}0.38^{* * *} \\
\left(1.2 \times 10^{-2}\right)\end{array}$ & $\begin{array}{c}0.38^{* * *} \\
\left(1.2 \times 10^{-2}\right)\end{array}$ \\
\hline $\begin{array}{l}\text { Executive and } \\
\text { intellectual } \\
\text { function }\end{array}$ & $\begin{array}{c}0.39^{* * *} \\
\left(6.1 \times 10^{-3}\right)\end{array}$ & $\begin{array}{c}0.38^{* * *} \\
\left(6.1 \times 10^{-3}\right)\end{array}$ & $\begin{array}{c}0.38^{* * *} \\
\left(6.1 \times 10^{-3}\right)\end{array}$ & $\begin{array}{c}0.37^{* * *} \\
\left(6.1 \times 10^{-3}\right)\end{array}$ & $\begin{array}{c}0.37^{* * *} \\
\left(6.1 \times 10^{-3}\right)\end{array}$ & $\begin{array}{c}0.38^{* * *} \\
\left(6.1 \times 10^{-3}\right)\end{array}$ \\
\hline Labor & $\begin{array}{c}0.32 * * * \\
\left(5 \times 10^{-3}\right) \\
\end{array}$ & $\begin{array}{c}0.33^{* * *} \\
\left(5 \times 10^{-3}\right) \\
\end{array}$ & $\begin{array}{c}0.33^{* * *} \\
\left(5 \times 10^{-3}\right) \\
\end{array}$ & $\begin{array}{c}0.33^{* * *} \\
\left(5 \times 10^{-3}\right) \\
\end{array}$ & $\begin{array}{c}0.33^{* * *} \\
\left(5 \times 10^{-3}\right) \\
\end{array}$ & $\begin{array}{c}0.33^{* * *} \\
\left(5 \times 10^{-3}\right) \\
\end{array}$ \\
\hline \multicolumn{7}{|l|}{$\begin{array}{c}\text { Family composed } \\
\text { of a couple of two } \\
\text { workers }\end{array}$} \\
\hline Single parent & $\begin{array}{c}-0.18^{* * *} \\
\left(7.2 \times 10^{-3}\right)\end{array}$ & $\begin{array}{c}-0.18^{* * *} \\
\left(7.2 \times 10^{-3}\right)\end{array}$ & $\begin{array}{c}-0.18^{* * *} \\
\left(7.2 \times 10^{-3}\right)\end{array}$ & $\begin{array}{c}-0.18^{* * *} \\
\left(7.2 \times 10^{-3}\right)\end{array}$ & $\begin{array}{c}-0.18^{* * *} \\
\left(7.2 \times 10^{-3}\right)\end{array}$ & $\begin{array}{c}-0.18^{* * *} \\
\left(7.2 \times 10^{-3}\right)\end{array}$ \\
\hline $\begin{array}{l}\text { Family with } \\
\text { one parent and } \\
\text { children }\end{array}$ & $\begin{array}{c}-0.12^{* * *} \\
\left(6.5 \times 10^{-3}\right)\end{array}$ & $\begin{array}{c}-0.12^{* * *} \\
\left(6.5 \times 10^{-3}\right)\end{array}$ & $\begin{array}{c}-0.12^{* * *} \\
\left(6.5 \times 10^{-3}\right)\end{array}$ & $\begin{array}{c}-0.12^{* * *} \\
\left(6.5 \times 10^{-3}\right)\end{array}$ & $\begin{array}{c}-0.12^{* * *} \\
\left(6.5 \times 10^{-3}\right)\end{array}$ & $\begin{array}{c}-0.12^{* * *} \\
\left(6.5 \times 10^{-3}\right)\end{array}$ \\
\hline $\begin{array}{l}\text { Family } \\
\text { composed of a } \\
\text { couple with } \\
\text { only one } \\
\text { worker }\end{array}$ & $\begin{array}{c}-0.34^{* * *} \\
\left(6.9 \times 10^{-3}\right)\end{array}$ & $\begin{array}{c}-0.34^{* * *} \\
\left(6.9 \times 10^{-3}\right)\end{array}$ & $\begin{array}{c}-0.34^{* * *} \\
\left(6.9 \times 10^{-3}\right)\end{array}$ & $\begin{array}{c}-0.34^{* * *} \\
\left(6.9 \times 10^{-3}\right)\end{array}$ & $\begin{array}{c}-0.34^{* * *} \\
\left(6.9 \times 10^{-3}\right)\end{array}$ & $\begin{array}{c}-0.34^{* * *} \\
\left(6.9 \times 10^{-3}\right)\end{array}$ \\
\hline \multicolumn{7}{|l|}{ House } \\
\hline Apartment & $\begin{array}{c}-0.54^{* * *} \\
\left(4.1 \times 10^{-3}\right) \\
\end{array}$ & $\begin{array}{c}-0.54^{* * *} \\
\left(4.1 \times 10^{-3}\right)\end{array}$ & $\begin{array}{c}-0.54^{* * *} \\
\left(4.1 \times 10^{-3}\right) \\
\end{array}$ & $\begin{array}{c}-0.54^{* * *} \\
\left(4.1 \times 10^{-3}\right) \\
\end{array}$ & $\begin{array}{c}-0.55^{* * *} \\
\left(4.1 \times 10^{-3}\right) \\
\end{array}$ & $\begin{array}{c}-0.54^{* * *} \\
\left(4.1 \times 10^{-3}\right) \\
\end{array}$ \\
\hline
\end{tabular}


Table 2. Cont.

\begin{tabular}{|c|c|c|c|c|c|c|}
\hline & Population & $\begin{array}{l}\text { Jobs-Housing } \\
\text { Ratio }\end{array}$ & $\begin{array}{c}\text { Dwelling } \\
\text { Vacancy Rate }\end{array}$ & Worker Rate & $\begin{array}{l}\text { Unemployment } \\
\text { Rate }\end{array}$ & Executive Rate \\
\hline \multicolumn{7}{|l|}{3 people } \\
\hline 2 people & $\begin{array}{c}-0.07^{* * *} \\
\left(4.7 \times 10^{-3}\right)\end{array}$ & $\begin{array}{c}-0.07^{* * *} \\
\left(4.7 \times 10^{-3}\right)\end{array}$ & $\begin{array}{c}-0.07^{* * *} \\
\left(4.7 \times 10^{-3}\right)\end{array}$ & $\begin{array}{c}-0.07^{* * *} \\
\left(4.7 \times 10^{-3}\right)\end{array}$ & $\begin{array}{c}-0.07^{* * *} \\
\left(4.7 \times 10^{-3}\right)\end{array}$ & $\begin{array}{c}-0.07^{* * *} \\
\left(4.7 \times 10^{-3}\right)\end{array}$ \\
\hline 4 people & $\begin{array}{c}0.02 * * * \\
\left(5.1 \times 10^{-3}\right)\end{array}$ & $\begin{array}{c}0.02 * * * \\
\left(5.1 \times 10^{-3}\right)\end{array}$ & $\begin{array}{c}0.02 * * * \\
\left(5.1 \times 10^{-3}\right)\end{array}$ & $\begin{array}{c}0.02 * * * \\
\left(5.1 \times 10^{-3}\right)\end{array}$ & $\begin{array}{c}0.02 * * * \\
\left(5.1 \times 10^{-3}\right)\end{array}$ & $\begin{array}{c}0.02^{* * *} \\
\left(5.1 \times 10^{-3}\right)\end{array}$ \\
\hline 5 people & $\begin{array}{c}-0.13^{* * *} \\
\left(7 \times 10^{-3}\right)\end{array}$ & $\begin{array}{c}-0.14^{* * *} \\
\left(7 \times 10^{-3}\right) \\
\end{array}$ & $\begin{array}{c}-0.14^{* * *} \\
\left(7 \times 10^{-3}\right)\end{array}$ & $\begin{array}{c}-0.14^{* * *} \\
\left(7 \times 10^{-3}\right)\end{array}$ & $\begin{array}{c}-0.14^{* * *} \\
\left(7 \times 10^{-3}\right) \\
\end{array}$ & $\begin{array}{c}-0.14^{* * *} \\
\left(7 \times 10^{-3}\right) \\
\end{array}$ \\
\hline $\begin{array}{l}6 \text { people or } \\
\text { more }\end{array}$ & $\begin{array}{c}-0.27^{* * *} \\
\left(4.9 \times 10^{-2}\right)\end{array}$ & $\begin{array}{c}-0.28^{* * *} \\
\left(4.9 \times 10^{-2}\right)\end{array}$ & $\begin{array}{c}-0.28^{* * *} \\
\left(4.9 \times 10^{-2}\right)\end{array}$ & $\begin{array}{c}-0.28^{* * *} \\
\left(4.9 \times 10^{-2}\right)\end{array}$ & $\begin{array}{c}-0.28^{* * *} \\
\left(4.9 \times 10^{-2}\right)\end{array}$ & $\begin{array}{c}-0.28^{* * *} \\
\left(4.9 \times 10^{-2}\right)\end{array}$ \\
\hline \multicolumn{7}{|l|}{$\begin{array}{l}\text { No limit jobs. } \\
\text { Public service } \\
\text { worker }\end{array}$} \\
\hline $\begin{array}{l}\text { Placed by a } \\
\text { temporary } \\
\text { employment } \\
\text { agency }\end{array}$ & $\begin{array}{l}-1.13^{* * *} \\
\left(1 \times 10^{-2}\right)\end{array}$ & $\begin{array}{l}-1.20^{* * *} \\
\left(1 \times 10^{-2}\right)\end{array}$ & $\begin{array}{l}-1.20^{* * *} \\
\left(1 \times 10^{-2}\right)\end{array}$ & $\begin{array}{l}-1.20^{* * *} \\
\left(1 \times 10^{-2}\right)\end{array}$ & $\begin{array}{l}-1.20^{* * *} \\
\left(1 \times 10^{-2}\right)\end{array}$ & $\begin{array}{l}-1.20^{* * *} \\
\left(1 \times 10^{-2}\right)\end{array}$ \\
\hline $\begin{array}{c}\text { Other } \\
\text { short-term } \\
\text { work }\end{array}$ & $\begin{array}{c}-0.31^{* * *} \\
\left(5.4 \times 10^{-3}\right)\end{array}$ & $\begin{array}{c}-0.33^{* * *} \\
\left(5.4 \times 10^{-3}\right)\end{array}$ & $\begin{array}{c}-0.34^{* * *} \\
\left(5.4 \times 10^{-3}\right)\end{array}$ & $\begin{array}{c}-0.34^{* * *} \\
\left(5.4 \times 10^{-3}\right)\end{array}$ & $\begin{array}{c}-0.34^{* * *} \\
\left(5.4 \times 10^{-3}\right)\end{array}$ & $\begin{array}{c}-0.33^{* * *} \\
\left(5.4 \times 10^{-3}\right)\end{array}$ \\
\hline \multicolumn{7}{|l|}{ Female } \\
\hline Male & $\begin{array}{c}0.07^{* * *} \\
\left(4.5 \times 10^{-3}\right)\end{array}$ & $\begin{array}{c}0.07^{* * *} \\
\left(4.5 \times 10^{-3}\right)\end{array}$ & $\begin{array}{c}0.07^{* * *} \\
\left(4.5 \times 10^{-3}\right)\end{array}$ & $\begin{array}{c}0.07^{* * *} \\
\left(4.5 \times 10^{-3}\right)\end{array}$ & $\begin{array}{c}0.07^{* * *} \\
\left(4.5 \times 10^{-3}\right)\end{array}$ & $\begin{array}{c}0.07^{* * *} \\
\left(4.5 \times 10^{-3}\right)\end{array}$ \\
\hline \multicolumn{7}{|l|}{2006} \\
\hline 2016 & $\begin{array}{c}0.28^{* * *} \\
\left(2.0 \times 10^{-2}\right)\end{array}$ & $\begin{array}{c}0.31^{* * *} \\
\left(6.0 \times 10^{-2}\right)\end{array}$ & $\begin{array}{c}0.18^{* * *} \\
\left(3.0 \times 10^{-2}\right)\end{array}$ & - & $\begin{array}{c}0.17^{* * *} \\
\left(4.4 \times 10^{-2}\right)\end{array}$ & $\begin{array}{c}0.38^{* * *} \\
\left(3.2 \times 10^{-2}\right)\end{array}$ \\
\hline \multicolumn{7}{|l|}{ Suburban ring } \\
\hline Urban ring & $\begin{array}{c}-0.16^{* * *} \\
\left(1.8 \times 10^{-2}\right)\end{array}$ & $\begin{array}{c}0.23^{* * *} \\
\left(4.9 \times 10^{-2}\right)\end{array}$ & $\begin{array}{c}-0.47^{* * *} \\
\left(2.5 \times 10^{-2}\right) \\
\end{array}$ & - & $\begin{array}{c}-0.55^{* * *} \\
\left(3.4 \times 10^{-2}\right)\end{array}$ & $\begin{array}{c}-0.17^{* * *} \\
\left(3.1 \times 10^{-2}\right)\end{array}$ \\
\hline Center town & $\begin{array}{c}-0.58^{* * *} \\
\left(1.5 \times 10^{-2}\right) \\
\end{array}$ & $\begin{array}{c}0.14^{* *} \\
\left(4.7 \times 10^{-2}\right)\end{array}$ & $\begin{array}{c}-0.48^{* * *} \\
\left(2.2 \times 10^{-2}\right)\end{array}$ & $\begin{array}{c}-0.73^{* * *} \\
\left(1.4 \times 10^{-2}\right)\end{array}$ & $\begin{array}{c}-0.74^{* * *} \\
\left(3.0 \times 10^{-2}\right)\end{array}$ & $\begin{array}{c}-0.41^{* * *} \\
\left(2.8 \times 10^{-2}\right)\end{array}$ \\
\hline Indicator & - & $\begin{array}{c}0.38^{* * *} \\
\left(3.0 \times 10^{-2}\right)\end{array}$ & $\begin{array}{c}0.75^{* *} \\
\left(2.3 \times 10^{-1}\right) \\
\end{array}$ & $\begin{array}{c}-0.45^{\text {** }} \\
\left(1.7 \times 10^{-1}\right)\end{array}$ & $\begin{array}{c}-1.47^{* * *} \\
\left(1.7 \times 10^{-1}\right)\end{array}$ & $\begin{array}{c}1.29^{* * *} \\
\left(1.9 \times 10^{-1}\right)\end{array}$ \\
\hline $\begin{array}{l}\text { Indicator * } \\
\text { Urban ring }\end{array}$ & $\begin{array}{c}-1.9 \times 10^{-6 * * *} \\
\left(4.0 \times 10^{-7}\right)\end{array}$ & $\begin{array}{c}-0.3^{* * *} \\
\left(3.4 \times 10^{-2}\right)\end{array}$ & $\begin{array}{c}3.02^{* * *} \\
\left(2.9 \times 10^{-1}\right)\end{array}$ & - & $\begin{array}{c}2.03^{* * *} \\
\left(2.1 \times 10^{-3}\right)\end{array}$ & - \\
\hline $\begin{array}{l}\text { Indicator }{ }^{*} \\
\text { Center town }\end{array}$ & $\begin{array}{c}-1.0 \times 10^{-6} * * * \\
\left(3.3 \times 10^{-7}\right)\end{array}$ & $\begin{array}{c}-0.5^{* * *} \\
\left(3.3 \times 10^{-2}\right)\end{array}$ & $\begin{array}{c}-2.47^{* * *} \\
\left(2.6 \times 10^{-1}\right)\end{array}$ & - & $\begin{array}{c}0.85^{* * *} \\
\left(2.0 \times 10^{-3}\right)\end{array}$ & $\begin{array}{c}-2.13^{* * *} \\
\left(2.3 \times 10^{-3}\right)\end{array}$ \\
\hline Indicator * 2016 & - & - & $\begin{array}{c}0.70 * \\
\left(3.1 \times 10^{-1}\right)\end{array}$ & - & $\begin{array}{c}0.93^{* * *} \\
\left(2.4 \times 10^{-3}\right)\end{array}$ & $\begin{array}{c}-0.85^{* * *} \\
\left(2.4 \times 10^{-3}\right)\end{array}$ \\
\hline $\begin{array}{l}\text { Urban ring * } \\
2016\end{array}$ & $\begin{array}{c}-0.2^{* * *} \\
\left(2.7 \times 10^{-2}\right)\end{array}$ & $\begin{array}{c}-0.52^{* * *} \\
\left(6.9 \times 10^{-2}\right)\end{array}$ & $\begin{array}{c}-0.15^{* * *} \\
\left(3.8 \times 10^{-2}\right)\end{array}$ & $\begin{array}{c}1.01^{* * *} \\
\left(2.2 \times 10^{-1}\right)\end{array}$ & $\begin{array}{c}-0.17^{* * *} \\
\left(5.4 \times 10^{-2}\right)\end{array}$ & $\begin{array}{c}-0.2^{* * *} \\
\left(4.2 \times 10^{-2}\right)\end{array}$ \\
\hline $\begin{array}{l}\text { Center town * } \\
2016\end{array}$ & $\begin{array}{c}-0.2^{* * *} \\
\left(2.2 \times 10^{-2}\right)\end{array}$ & $\begin{array}{c}-0.23^{* * *} \\
\left(6.5 \times 10^{-2}\right)\end{array}$ & $\begin{array}{c}-0.18^{* * *} \\
\left(3.4 \times 10^{-2}\right)\end{array}$ & $\begin{array}{c}-0.73^{* * *} \\
\left(2.0 \times 10^{-1}\right)\end{array}$ & . & $\begin{array}{c}-0.11^{* *} \\
\left(3.8 \times 10^{-2}\right)\end{array}$ \\
\hline $\begin{array}{l}\text { Indicator * } \\
\text { Urban ring * } \\
2016\end{array}$ & $\begin{array}{c}-1.8 \times 10^{-6} * * \\
\left(5.9 \times 10^{-7}\right)\end{array}$ & $\begin{array}{c}0.3^{* * *} \\
\left(4.8 \times 10^{-2}\right)\end{array}$ & - & $\begin{array}{c}-1.6^{* * *} \\
\left(3.2 \times 10^{-1}\right)\end{array}$ & - & $\begin{array}{c}0.66^{*} \\
\left(3.2 \times 10^{-1}\right)\end{array}$ \\
\hline
\end{tabular}


Table 2. Cont.

\begin{tabular}{|c|c|c|c|c|c|c|}
\hline & Population & $\begin{array}{c}\text { Jobs-Housing } \\
\text { Ratio }\end{array}$ & $\begin{array}{c}\text { Dwelling } \\
\text { Vacancy Rate }\end{array}$ & Worker Rate & $\begin{array}{c}\text { Unemployment } \\
\text { Rate }\end{array}$ & Executive Rate \\
\hline $\begin{array}{l}\text { Indicator * } \\
\text { Center town * } \\
2016\end{array}$ & - & - & - & $\begin{array}{c}0.76^{* *} \\
\left(2.9 \times 10^{-1}\right)\end{array}$ & - & \\
\hline McFadden $\mathrm{R}^{2}$ & 0.0771 & 0.0776 & 0.0777 & 0.0773 & 0.0772 & 0.0775 \\
\hline
\end{tabular}

In Table 1 , the $\mathrm{R}^{2} \mathrm{~s}$ of the models are low $(0.11)$, as are most of the models in the very large CENSUS samples that explain commuting distances [21,36]. A large share of the distances is, therefore, not explained by the models, and in these models, a large share is explained by individual variables. However, the aim of this research was not to explain commuting distance but to understand the influence of certain significant variables. Concerning the car modal share, MacFadden's $\mathrm{R}^{2}$ was added in Table 2 to reflect how well the logit model fits the data (0.077). Low values have the same origins as for the commuting distance. The characteristics of cities are secondary but have an influence on mobility behaviors and are often significant in our models. By controlling for the sociodemographic variables of residents, we confirmed the results of the previous section: the effect of the year variable "2016" is positive whatever the model for the modal share of car and for commuting distances to the workplace, as estimated over the same periods in the United States [36] and the United Kingdom [22]. To clarify the results, parameters whose values were too close to zero were removed. Nonsignificant attributes of variables or of poor interest were removed from Tables 1 and 2; thus, some attributes are in Table 2 but not in Table 1. On the variables that characterize revitalization, the standard deviation was added to better highlight the significance of the sign of the parameters, i.e., the positive or negative influence of the parameter on the explained variable.

Regarding the characteristics of residents of mid-sized cities, the coefficients of these individual variables are stable in all models because they are independent. Part-time working is negatively related to distances and the modal share of cars. Adults in families with several children use the car more and travel longer distances, controlling for the effect of place of residence, with families more often living in suburban areas. As seen in other studies, women use the car less than men and work less far away [36]. Insecure employees, on the other hand, logically travel further than employees with stable contracts because they do not necessarily choose their workplace. However, they use the car less. It is interesting to note that executives travel further than employees and laborers [38], who represent the majority in mid-sized cities. Mechanically, increasing the proportion of executives in the mid-sized city should, therefore, mechanically increase the average car distances. However, in the models on the rate of executives in the central city, the parameters are slightly negative. This would mean that the increase in the executive rate is correlated with a decrease in the use of cars by residents of the central city. The opposite effect is observed in the peripheral municipalities, which could be explained by a different socio-professional organization depending on the city. Cities that increase their executive rate in the center would decrease it in the periphery. A higher proportion of employees and workers in the suburban area would then be linked to lower car use in these areas.

To take into account changes in mobility behavior between 2006 and 2016, a year variable was included in the model. This variable is not completely independent of the other variables, so we added interaction effects to the model by crossing the key variables of our model: the year, the urban type and the revitalization variable. Thus, the model estimated a general effect for each variable and interaction effects between 2 variables and 3 variables. For the increase in the share of vacant dwellings in the central town, the effect on distances is on average decreasing, in contrast to the car modal share. The difference 
in impact on distances and car use between the center and the periphery is significant. Compared to the periphery, the increase in vacancy in the central city is negatively related to the distances of central city residents, as is the case for car usage. However, this gap decreased in the central city in 2016 compared to 2006. In summary, the effect of a decrease in the share of vacant dwellings as an indicator of revitalization is not obvious. Cheshire et al. [22] found the effect of an increase in distance in England, but as a collateral effect of an increase in vacancy due to land use regulation policies. The effect of an increase in the population of the central town is neutral on the car modal share of each worker. On the other hand, the increase in population in 2016 was associated with shorter distances. The distances are also shorter for the suburban ring than for the city center when the population of the city center increases. The parameters of the variables in the commuting distance model for this indicator are very small, but are associated with a population of more than 10,000 workers. The rest of the indicators relate directly to workers. The increase in the share of workers in the population aged 15-64 has a negative average effect on distances to the workplace and the use of cars, but the effect was positive in 2016 compared to 2006. The effect in the central town is positive in relation to the suburban ring for distance and car use and negative in the urban ring. But in 2016, with the worker rate increasing, the commuting distance in the suburban ring decreased more than in the central town. The parameters of the unemployment rate are negative for distance and car use but were positive in 2016. An increase in the unemployment rate is associated with greater distances in the suburban ring but a lower modal share of the car. Regarding the jobs-housing ratio, an increase in the number of jobs per worker increases commuting distances and the modal share of the car. The effect on distances increased in 2016. The effect on the decrease in the modal share is greater in the center than in the urban area. Woo [19] also showed a positive effect of the jobs-housing ratio on distances traveled and on the modal choice, but only on the new inhabitants of areas where this rate has increased. An increase in the executive rate is positively related to the commuting distance and the car modal share, but negatively in 2016. It is also associated with a shorter distance and a smaller car modal share in the central town than in the rest of the urban area.

Table 3 summarizes the different effects for the different revitalization indicators on the distances and modal share of the private car. A "+" corresponds to a benefit, i.e., a reduction in distances or a decrease in the modal share of the car. The most significant effects are obviously visible in the central town, but the indicators can have opposite effects. For instance, growth in the jobs-housing ratio decreases commuting trip distances but increases car use in the urban ring. The increase in the population in the central town increases the commuting distances in the center of the urban areas. On average, for the 5 other indicators, the most beneficial effects seem to be in the urban ring.

Table 3. Summary of effects by urban type.

\begin{tabular}{|c|c|c|c|c|}
\hline & & Central Town & Urban Ring & Suburban Ring \\
\hline \multirow{2}{*}{ Population growth } & Distance & - & - & \\
\hline & Modal shift & & & \\
\hline \multirow{2}{*}{ Jobs-housing ratio growth } & Distance & ++ & + & \\
\hline & Modal shift & & - & \\
\hline \multirow{2}{*}{ Dwelling vacancy rate reduction } & Distance & -- & + & - \\
\hline & Modal shift & & + & + \\
\hline \multirow{2}{*}{ Worker rate growth } & Distance & - & + & + \\
\hline & Modal shift & - & & \\
\hline
\end{tabular}


Table 3. Cont.

\begin{tabular}{ccccc}
\hline \multirow{2}{*}{ Unemployment rate reduction } & & Central Town & Urban Ring & Suburban Ring \\
\cline { 2 - 5 } & Distance & - & + & - \\
\hline \multirow{2}{*}{ Executive rate growth } & Modal shift & + & + & - \\
\cline { 2 - 5 } & Distance & & - \\
\hline
\end{tabular}

Legend: white case: no significant effect. --: important negative effect. -: negative effect. +: beneficial effect. ++: important beneficial effect.

\section{Discussion}

Contrasting conclusions were obtained from the statistical models according to revitalization indicators and urban types. While mid-sized cities changed a lot between 2006 and 2016 in terms of employment dynamics and worker population, the effect of these dynamics on car use in central towns is quite mixed. The results often show opposite effects between residents of the central town and those of the periphery and opposite effects between distances traveled and car use. Not every revitalization indicator has the same influence on mobility behavior. Proposing a revitalization that cumulates benefits on the six indicators studied does not have an obvious effect on practices and, therefore, on GHG emissions.

The dynamics studied between 2006 and 2016 provide a perspective of urban policies in shrinking mid-sized cities. If, as our results show, an increase in population is associated with an increase in GHGs for each individual, right-sizing policies would be more virtuous for GHGs than revitalization policies from this point of view. The other indicators studied can be associated with both types of urban policies and must be studied separately according to the policies of each territory. However, it can be considered that independently of the effect of the revitalization factors, the effect of residing in the central town is, in most of the models studied, associated with a practice of mobility with a lower carbon footprint than in the rest of the agglomeration. The policy of increasing the number of workers residing in the central city would, therefore, be positive in terms of commuting trip carbon emissions, even if the gain is not directly due to the policy but to the urban context of the central town (density, functional mix, etc.) [8].

An important conclusion of this study is also a better understanding of the increase in GHG emissions from commuting between 2006 and 2016 in our study area. In view of the very mixed results, this strong increase would be due to individual effects, structural effects or effects of the extension of the agglomeration, but the increase due to effects of reduced vitality in the central city would be very limited.

The first point of discussion of the results is our attempt to capture a phenomenon of revitalization that was rare between 2006 and 2016 [14]. The model then risks estimating the opposite of the devitalization effect by considering that the dynamics are perfectly opposite. The lack of data does not allow us to isolate cities with a revitalization dynamic without taking the risk of capturing other effects specific to these cities. A study in China, where there are many shrinking cities and growth dynamics [24], would enable us to compare the effects on mobility according to the city's dynamics.

In France, commercial vacancy is the most visible manifestation of the difficulties of mid-sized city centers $[39,40]$. The modernization of retail stores is at the heart of the city center project. Competition with shopping malls on the periphery and the dispersal of purchases, especially to areas accessible only by car, is obviously central for mid-sized cities [41]. Shopping trips in mid-sized cities account for 13\% of distances traveled by car, while commuting trips account for 35\% (French Household Travel Survey analysis). The two purposes are partly linked, and a city center that is dynamic in terms of employment and attracts wealthy populations, such as executives, can be linked to the commercial dynamics of the city. 
The aim of the revitalization of city centers is to renovate a certain number of insalubrious housing units that were a consequence, but also a cause, of the lack of attractiveness of the city center [30]. The environmental benefit of this renovation for carbon emissions is certainly much higher than for travel. However, if the principle of promoting the concentration of jobs and populations in the city center tends to favor energy sobriety, a certain number of pitfalls must be anticipated.

First of all, the absence of strict planning rules at the level of agglomerations and catchment areas, particularly for the construction of housing and commercial spaces, does not promote the revitalization of city centers or lead to energy sobriety [18]. Transportation policies, which were not considered in this study because they are marginal in mid-sized cities, should accompany these urban policies for greater efficiency. Modal policies in favor of cycling or walking are relevant at the mid-sized city level.

Moreover, in mid-sized cities, the quality of life is often promoted [1] to attract metropolitans in search of green spaces, whose residential space is restricted by excessively high real estate prices. The current period of active diffusion of the COVID-19 virus and the resulting measures to limit its spread in large metropolitan areas is encouraging metropolitans to move to less dense areas, especially mid-sized cities [42]. If this move is accompanied by a switch in their employment to the mid-sized city, the environmental benefits of commuting can be positive. On the other hand, if employment in the metropolis is maintained, the commuting distances can be quite significant and so are the $\mathrm{CO}_{2}$ emissions associated with these trips. Studies have shown that an increasing proportion of interurban commuters greatly increases the commuting distances covered by car [33]. Considering that an interurban commuter is a worker who commutes by car over distances greater than $40 \mathrm{~km}$, in our study area, there were $2.7 \%$ of them in 2006 and $5.1 \%$ in 2016.

Teleworking, also currently highly discussed and in full expansion, should limit the modal share of the car. However, it encourages households to live in a mid-sized city while keeping a job in a large metropolitan area. While the economic effects have often been studied, particularly on the redistribution of wealth between large metropolitan areas and the rest of the country [43], the impact of telework on the mobility of these interurban commuters has been much less studied. Recent studies on telework have relativized its impact on the distances traveled by considering the totality of individuals' journeys [43].

To conclude, the dynamics of work organization with the development of telework should be favorable to population growth in mid-sized cities. The reduction in GHG emissions from commuting trips must be studied in light of these recent dynamics.

Author Contributions: Conceptualization, A.P.; methodology, A.P. and A.B.; formal analysis, A.P. and A.B.; investigation, A.P. and A.B.; resources, A.B.; data curation, A.B.; writing-original draft preparation, A.P. and A.B.; writing-review and editing, A.P.; visualization, A.B. All authors have read and agreed to the published version of the manuscript.

Funding: This research received no external funding.

Institutional Review Board Statement: Not applicable.

Informed Consent Statement: Not applicable.

Data Availability Statement: No new data were created or analyzed in this study. Data sharing is not applicable to this article.

Conflicts of Interest: The authors declare no conflict of interest.

\section{References}

1. Talmage, C.A.; Frederick, C. Quality of Life, Multimodality, and the Demise of the Autocentric Metropolis: A Multivariate Analysis of 148 Mid-Size U.S. Cities. Soc. Indic. Res. 2019, 141, 365-390. [CrossRef]

2. Martinez-Fernandez, C.; Audirac, I.; Fol, S.; Cunningham-Sabot, E. Shrinking Cities: Urban Challenges of Globalization. Int. J. Urban Reg. Res. 2012, 36, 213-225. [CrossRef] [PubMed]

3. Taulelle, F. Chapitre 8-La France des Villes Petites et Moyennes. In La France, une Géographie Urbaine; Armand Colin: Paris, France, 2010; pp. 149-168. ISBN 978-2-200-25579-4. 
4. Béal, V.; Fol, S.; Miot, Y.; Rousseau, M. Varieties of right-sizing strategies: Comparing degrowth coalitions in French shrinking cities. Urban Geogr. 2019, 40, 192-214. [CrossRef]

5. CGET. Action Coeur de Ville, Dossier de Présentation; Ministère de la Cohésion des Territoires: Paris, France, 2018. Available online: https://www.cohesion-territoires.gouv.fr/sites/default/files/2019-07/plaquette_actioncoeurdeville_0_2.pdf (accessed on 29 January 2021).

6. Newman, P.W.G.; Kenworthy, J.R. Cities and Automobile Dependence. An International Sourcebook; Gower Publishing: Brookfield, VT, USA, 1989.

7. Hickman, R.; Banister, D. Reducing Travel by Design: Urban Form and the Commute to Work; Association for European Transport: Henley-in-Arden, UK, 2004.

8. Cervero, R.; Kockelman, K. Travel demand and the 3Ds: Density, diversity, and design. Transp. Res. Part D Transp. Environ. 1997, 2, 199-219. [CrossRef]

9. Cirilli, A.; Veneri, P. Spatial Structure and Carbon Dioxide $\left(\mathrm{CO}_{2}\right)$ Emissions Due to Commuting: An Analysis of Italian Urban Areas. Reg. Stud. 2014, 48, 1993-2005. [CrossRef]

10. Herrmann, D.; Shuster, W.; Mayer, A.; Garmestani, A. Sustainability for Shrinking Cities. Sustainability 2016, 8, 911. [CrossRef]

11. Beauregard, R.A. Urban Population Loss in Historical Perspective: United States, 1820-2000. Environ. Plan A 2009, 41, 514-528. [CrossRef]

12. Hartt, M. The diversity of North American shrinking cities. Urban Stud. 2018, 55, 2946-2959. [CrossRef]

13. Wolff, M.; Wiechmann, T. Urban growth and decline: Europe's shrinking cities in a comparative perspective 1990-2010. Eur. Urban Reg. Stud. 2018, 25, 122-139. [CrossRef]

14. Wolff, M.; Fol, S.; Roth, H.; Cunningham-Sabot, E. Shrinking Cities, villes en décroissance: Une mesure du phénomène en France. Cybergeo 2013. [CrossRef]

15. Zheng, H.W.; Shen, G.Q.; Wang, H. A review of recent studies on sustainable urban renewal. Habitat Int. 2014, 41, 272-279. [CrossRef]

16. Ramlee, M.; Omar, D.; Yunus, R.M.; Samadi, Z. Revitalization of Urban Public Spaces: An Overview. Proc. Soc. Behav. Sci. 2015, 201, 360-367. [CrossRef]

17. Bereitschaft, B. Gentrification and the evolution of commuting behavior within America's urban cores, 2000-2015. J. Transp. Geogr. 2020, 82, 102559. [CrossRef]

18. Nelson, A.C.; Burby, R.J.; Feser, E.; Dawkins, C.J.; Malizia, E.E.; Quercia, R. Urban Containment and Central-City Revitalization. J. Am. Plan. Assoc. 2004, 70, 411-425. [CrossRef]

19. Woo, Y.-S. An Analysis of Commuting Distance and Mode Changes of Recent Migrations to Housing Renewal Areas. Int. Rev. Public Adm. 2005, 10, 95-108. [CrossRef]

20. Florida, R. Cities and the Creative Class. City Commun. 2003, 2, 3-19. [CrossRef]

21. Blumenberg, E.; King, H. Low-Income Workers, Residential Location, and the Changing Commute in the United States. Built Environ. 2019, 45, 563-581. [CrossRef]

22. Cheshire, P.; Hilber, C.A.L.; Koster, H.R.A. Empty homes, longer commutes: The unintended consequences of more restrictive local planning. J. Public Econ. 2018, 158, 126-151. [CrossRef]

23. Xiao, H.; Duan, Z.; Zhou, Y.; Zhang, N.; Shan, Y.; Lin, X.; Liu, G. $\mathrm{CO}_{2}$ emission patterns in shrinking and growing cities: A case study of Northeast China and the Yangtze River Delta. Appl. Energy 2019, 251, 113384. [CrossRef]

24. Liu, X.; Wang, M.; Qiang, W.; Wu, K.; Wang, X. Urban form, shrinking cities, and residential carbon emissions: Evidence from Chinese city-regions. Appl. Energy 2020, 261, 114409. [CrossRef]

25. Bolay, J.-C.; Rabinovich, A. Intermediate cities in Latin America risk and opportunities of coherent urban development. Cities 2004, 21, 407-421. [CrossRef]

26. Santamaria, F. La notion de "ville moyenne" en France, en Espagne et au Royaume-Uni//The notion of "medium-sized town" in France, Spain and the United Kingdom. Ann. Geogr. 2000, 109, 227-239. [CrossRef]

27. De Roo, P. Les Villes Moyennes Françaises: Enjeux et Perspectives; La Documentation Française; Collection Travaux: Paris, France, 2007.

28. Rousseau, M. La densité fait-elle la mixité? Politiques de densification et inégalités territoriales dans l'agglomération de Lyon. Soc. Contemp. 2017, 107, 23. [CrossRef]

29. Recoquillon, C. Les enjeux de la revitalisation urbaine: Harlem, du ghetto au quartier chic. Hérodote 2009, 132, 181-201. [CrossRef]

30. Berroir, S.; Fol, S.; Quéva, C.; Santamaria, F. Villes moyennes et dévitalisation des centres: Les politiques publiques face aux enjeux d'égalité territoriale. Belgeo 2019. [CrossRef]

31. Newman, O. Defensible Space: A New Physical Planning Tool for Urban Revitalization. J. Am. Plan. Assoc. 1995, 61, 149-155. [CrossRef]

32. Bacqué, H.; Divay, G.; Rose, D.; Séguin, A.-M. Survol de Quelques Politiques de Revitalisation Urbaine; Centre Urbanisation Culture Société: Quebec City, QC, Canada, 2003.

33. Conti, B. Modal shift and interurban mobility: Environmentally positive, socially regressive. J. Transp. Geogr. 2018, 69, $234-241$. [CrossRef]

34. Kim, S.-N. Is telecommuting sustainable? An alternative approach to estimating the impact of home-based telecommuting on household travel. Int. J. Sustain. Transp. 2017, 11, 72-85. [CrossRef] 
35. Bouzouina, L.; Quetelard, B.; Toilier, F. Émissions de $\mathrm{CO}_{2}$ liées à la mobilité domicile-travail: Une double lecture par le lieu de résidence et le lieu de travail des actifs à Lyon et à Lille. Dev. Durable Territ. 2013, 4. Available online: https://journals. openedition.org/developpementdurable/10018 (accessed on 29 January 2021). [CrossRef]

36. Plaut, P.O. The intra-household choices regarding commuting and housing. Transp. Res. Part A Policy Pract. 2006, 40, 561-571. [CrossRef]

37. Le Goff, F. Les logements vacants progressent plus vite que l'ensemble du parc. Insee Anal. 2018, 46. Available online: https: / www.insee.fr/fr/statistiques/3572856 (accessed on 29 January 2021).

38. Kersting, M.; Matthies, E.; Lahner, J.; Schlüter, J. A socioeconomic analysis of commuting professionals. Transportation 2020. [CrossRef]

39. Baëhr, A.; Courthial, M. Le commerce de centre -ville recule dans les villes moyennes. Insee Hauts-de-France 2020, 90. Available online: https: / / www.insee.fr / fr/statistiques / 4302996\#: \{\}:text=Regroupant\%20un\%20habitant\%20sur\%20cinq,recule\%20dans\% 20leurs\%20centres\%2Dvilles (accessed on 29 January 2021).

40. Razemon, O. Les Villes Moyennes vont Toujours plus Mal. Available online: https://www.lemonde.fr/blog/transports/2019/0 3/04/villes-moyennes-toujours-plus-mal/ (accessed on 22 November 2019).

41. Filion, P.; Hammond, K. When Planning Fails. Can. J. Urban Res. 2008, 17, 1-27.

42. Tendil, M. La Crise va-t-elle Engendrer un Exode Vers les Villes Moyennes? Banque des Territoires: Paris, France, 2020.

43. Davezies, L. La Crise Qui Vient. La Nouvelle Fracture Territoriale; Seuil: Paris, France, 2014. [CrossRef] 